\title{
IMPLEMENTASI PENDEKATAN SCIENTIFIC DENGAN METODE INKUIRI UNTUK MENINGKATKAN MINAT DAN HASIL BELAJAR IPA SISWA
}

\author{
oleh \\ Cok. Istri Agung Arista Dewi \\ (Guru SMP Negeri 1 Singaraja) \\ HP: 081337056708
}

\begin{abstract}
ABSTRAK
Penelitian tindakan kelas ini bertujuan mendeskripsikan peningkatan minat dan hasil belajar IPA siswa, implementasi melalui pendekatan scientific dengan metode inkuiri dalam meningkatkan kualitas pembelajaran IPA. Subjek penelitian ini adalah siswa kelas VIIIA5 SMP Negeri 1 Singgaraja sebanyak 28 orang yang dilaksanakan pada semester Genap tahun pelajaran 2014/2015. Data dikumpulkan dengan tes berbentuk objektif untuk mengukur aspek kognitif siswa, lembar observasi untuk sikap dan keterampilan siswa, kuisioner untuk minat dan tanggapan siswa terhadap metode pembelajaran yang diterapkan. Data dianalisis dengan statistik deskriptif. Hasil penelitian menunjukkan bahwa: (1) implementasi pendekatan scientific dengan metode inkuiri dalam pembelajaran IPA dapat meningkatkan minat siswa terhadap pelajaran IPA. Hal ini dapat ditunjukkan dari adanya peningkatan skor minat siswa pada siklus I sebesar 72 (kualifikasi tinggi) dan siklus II sebesar 82,45 (kualifikasi sangat tinggi), (2) implementasi pendekatan scientific dengan metode inkuiri dalam pembelajaran IPA dapat meningkatkan hasil belajar siswa, baik pada aspek kognitif, sikap, keterampilan dan hasil tes kognitif telah melampau KKM ( nilai KKM $\geq 78$ ). Peningkatan keterampilan proses sains siswa setelah mengikuti pelajaran IPA dengan metode inkuiri dapat dilihat dari adanya peningkatan sebesar 10,53\% (dari 17 pada siklus I menjadi 19 pada siklus II), (3) Respon siswa terhadap implementasi pendekatan scientific dengan metode inkuiri dengan nilai rata-rata 63,93 termasuk kategori sangat positif. Oleh karena itu, seyogyanya guru IPA di SMP dapat mengimplementasikan pendekatan scientific dengan metode inkuiri sebagai alternatif pembelajaran IPA, untuk meningkatkan minat dan hasil belajar
\end{abstract}

Kata kunci: inkuiri, metode, pendekatan, scientific

\begin{abstract}
This study aims to obtain empirical data about the impact of the application of scientific approach with inquiry method in science learning. This study was conducted following a classroom action research procedure with Kemmis \& Taggart design. The subjects of this study are students of class VIIIA5 SMP Negeri 1 Singgaraja in the even semester of the academic year 2014/2015 as many as 28 people. A number of data were collected with test techniques,
\end{abstract}


objective tests to measure aspects of student knowledge, observation sheets for student attitudes and skills, questionnaires for student interest and student responses to applied learning methods. The collected data were analyzed with descriptive statistics. The results showed that: (1) implementation of scientific approach with LSM-based inquiry method in science teaching can increase students' interest toward science lesson. this can be seen from the questionnaire results for student interest of 82.45 (very high qualification), (2) implementation of scientific approach with inquiry method based on LKS in science learning can improve student learning outcomes. The improvement of learning outcomes can be seen from the average score of attitude scores obtained score was 19 on cycle I and cycle II score of was 20 , so increased by was $5,26 \%$. While the results of cognitive tests with average student scores both in cycle I and cycle II reached values that exceeded KKM (KKM value $\geq 78$ ). As for the learning completeness classically increased from cycle I to cycle II of was was $3.49 \%$ (from $86 \%$ to $89 \%$ ) also exceeded the classical thoroughness indicator is $85 \%$. Improving students' science process skill after following IPA lesson with LKS-based inquiry method can be seen from the increase of student's average score of was 5,26\% (from 18 in cycle I to 19 in cycle II), (3) Student response to scientific approach with LSM-based inquiry method with an average value of 63,93 including very positive category. Based on the results of the research, the researcher's suggestion is: The teachers of science in junior high school who find the problems as mentioned in the development of learning innovation is expected to try to implement scientific approach with inquiry method as an alternative to science learning, to increase interest, learning result and student's response to learning.

Keywords: approach, inquiry, method, scientific.

\section{PENDAHULUAN}

Bagi sebagian besar siswa menyatakan bahwa Ilmu Pengetahuan Alam dirasakan sulit. Kesulitannya terletak pada pemahaman materi yang komplek dan abstrak. Hal ini juga sangat dirasakan oleh siswa kelas VIIIA5 SMP Negeri 1 Singaraja.

Kesulitan siswa terutama pada pemahaman konsep, karena materi yang komplek dan pemahaman-pemahaman rumit yang harus dikuasai oleh siswa. Kondisi ini menyebabkan rendahnya minat belajar siswa sehingga berdampak pada kurang optimalnya hasil belajar IPA siswa.

Penyajian materi IPA yang dianggap sulit dan membosankan disebabkan karena cara pembelajaran yang diterapkan belum melibatkan siswa secara utuh, sehingga siswa belajar hanya menghafal, selanjutnya hapalan itu akan hilang 
karena kegiatan menghafal bukan hal yang mudah menurut Negoro, S.T \& Harahap, B. (1984). Menurut Corey dalam Tileston, D.W. (2007) bahwa belajar adalah sebuah proses yang sangat berbeda dengan kegiatan memperhatikan.

Merupakan tanggung jawab guru untuk membuat suasana menyenangkan dan bermakna selama proses pembelajaran berlangsung sehingga siswa dapat terlibat total dan mampu mengeksplor pengetahuannya. Hal ini dapat meningkatkan minat dan hasil belajar IPA siswa.

Berdasarkan latar belakang masalah yang telah diuraikan, pokok permasalahan yang akan dikaji adalah: (1) Apakah penerapan pendekatan scientific dengan metode inkuiri dapat meningkatkan minat belajar IPA siswa?. (2) Apakah penerapan pendekatan scientific dengan metode inkuiri dapat meningkatkan hasil belajar IPA siswa ?. (3) Bagaimanakah respon siswa terhadap pendekatan scientific dengan metode inkuiri? Berdasarkan permasalahan tersebut maka tujuan penelitian ini adalah; (a) untuk mengetahui minat siswa dalam pelajaran IPA setelah mengikuti pembelajaran IPA melalui penerapan pendekatan scientific dengan metode inkuiri, (b) untuk mengetahui hasil belajar siswa dalam pelajaran IPA setelah mengikuti pembelajaran IPA melalui penerapan pendekatan scientific dengan metode inkuiri, dan (3) mendeskripsikan respon siswa terhadap pendekatan scientific dengan metode inkuiri.

Pendekatan saintifik atau pendekatan ilmiah (scientific approach) diyakini sebagai titian emas perkembangan dan pengembangan sikap, keterampilan, dan pengetahuan peserta didik dalam pendekatan atau proses kerja yang memenuhi kriteria ilmiah. Proses pembelajaran scientific merupakan perpaduan antara proses pembelajaran yang semula terfokus pada eksplorasi, elaborasi, dan konfirmasi dilengkapi dengan mengamati, menanya, menalar, mencoba, dan mengkomunikasikan. Berbagai strategi mengajar dengan pendekatan scintific yang menggunakan metode inkuiri telah diterapkan dalam usaha meningkatkan minat dan prestasi belajar IPA diantaranya: (1) Pengaruh model pembelajaran inkuiri terbimbing terhadap keterampilan proses sains dan penguasaan konsep IPA siswa kelas V gugus 03 Wanasaba Lombok, Suastra dkk (2013). Hasil penelitian menunjukkan bahwa model pembelajaran inkuiri terbimbing 
berpengaruh terhadap peningkatan keterampilan proses sains peserta didik karena keterampilan proses sains terintegrasi di dalam sintaks pembelajarannya. (2). Implementasi strategi pembelajaran inkuiri terhadap kemampuan berpikir kritis dan pemahaman konsep IPA siswa SMP, Ristiati dkk, (2013). Berdasarkan hasil penelitian secara diskriptif menunjukkan pola distribusi skor yang tidak sama antara kelompok siswa yang dibelajarkan dengan strategi pembelajaran inkuiri dengan kelompok siswa yang dibelajarkan dengan strategi pembelajaran langsung. (3) Analisis kebutuhan pengembangan model-model student centered learning untuk meningkatkan penalaran dan karakter siswa SMA, Santyasa dkk (2014). Penelitian ini mengungkap bahwa, belum adanya upaya-upaya guru, kepala sekolah, dan sekolah untuk melakukan pengembangan model-model Student Centered Learning.

Salah satu metode pembelajaran dalam sains adalah metode inkuiri. Inkuiri berarti pertanyaan, atau pemeriksaan, penyelidikan (Trianto, 2015:135). Dengan demikian inkuiri berkaitan dengan aktifitas dan keterampilan aktif yang fokus pada pencapaian pengetahuan atau pemahaman untuk memuaskan rasa ingin tahu. Lebih jauh dinyatakan bahwa inkuiri merupakan rangkaian kegiatan belajar yang melibatkan secara maksimal seluruh kemampuan siswa untuk mencari dan menyelidiki secara sistematis, kritis, logis, analitis, sehingga mereka dapat merumuskan sendiri penemuannya dengan penuh percaya diri. Selanjutnya metode inkuiri merupakan metode pembelajaran yang berupaya menanamkan dasar-dasar berpikir ilmiah pada diri siswa, sehingga dalam proses pembelajarannya siswa lebih banyak belajar sendiri, mengembangkan kreativitasnya dalam memecahkan masalah (Sutrino:2008). Siswa benar-benar ditempatkan sebagai subjek yang belajar. Peranan guru dalam pembelajaran dengan metode inkuiri adalah sebagai pembimbing dan fasilitator. Namun memungkinkan juga bahwa masalah yang akan dipecahkan dipilih oleh siswa. Tugas guru selanjutnya adalah menyediakan sumber belajar bagi siswa dalam rangka memecahkan masalah. Bimbingan dan pengawasan guru masih diperlukan, 
tetapi intervensi terhadap kegiatan siswa dalam pemecahan masalah harus dikurangi.

Hasil penelitian yang dilakukan oleh Suastra dkk (2013), Ristiati dkk, (2013). Menunjukan Pengaruh pembelajaran inkuiri terhadap peningkatan pada keterampilan proses, pemahaman konsep dan berpikir kritis siswa, tetapi penelitian tersebut belum mengkaji tentang pengaruh terhadap minat siswa. Oleh karena itu penulis tertarik untuk mengkaji lebih jauh tentang penerapan pendekatan scientific dengan metode inkuiri terhadap minat dan hasil belajar IPA siswa.

\section{METODE PENELITIAN}

Subjek penelitian tindakan kelas ini adalah siswa kelas VIIIA5 SMP Negeri 1 Singaraja, pada semester genap tahun pelajaran 2014/2015 yang berjumlah 28 orang. Pelaksanaannya dibagi menjadi empat tahapan kegiatan yang meliputi tahap perencanaan, tahap pelaksanaan, tahap observasi/ evaluasi, dan tahap refleksi. Penelitian ini dilaksanakan dalam dua siklus pembelajaran dengan materi pelajaran pada setiap siklus seperti ditunjukkan pada bagan berikut ini.

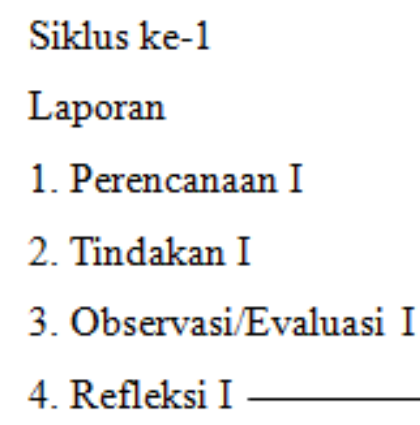

Data yang dikumpulkan dan instrumen yang digunakan dalam penelitian ini seperti disajikan pada Tabel 1. Minat siswa dalam penelitian ini adalah kecendurungan untuk memperhatikan dan tertarik terhadap pelajaran IPA. 
Tabel 1

Jenis Data, Metode, Instrumen, dan Waktu Pengambilan Data

\begin{tabular}{|l|l|l|l|}
\hline \multicolumn{1}{|c|}{ Jenis Data } & \multicolumn{1}{c|}{ Metode } & \multicolumn{1}{c|}{ Instrumen } & \multicolumn{1}{c|}{ Waktu } \\
\hline 1. Minat siswa & Kuis & Kuesioner & Akhir siklus \\
\hline $\begin{array}{l}\text { 2. Hasil Belajar: } \\
\text { a. Sikap ilmiah siswa }\end{array}$ & Observasi & Lembar observasi & $\begin{array}{l}\text { Saat pembelajaran } \\
\text { berlangsung } \\
\text { Pada akhir setiap siklus } \\
\text { Saat pembelajaran } \\
\text { berlangsung }\end{array}$ \\
$\begin{array}{l}\text { c. } \text { Keterampilan } \\
\text { proses IPA siswa }\end{array}$ & Tes Tulis & $\begin{array}{l}\text { Tes Objektif } \\
\text { Lembar observasi }\end{array}$ & Kuervasi \\
\hline 3. Respon siswa & Kuis & Kuesioner & Akhir siklus kedua \\
\hline
\end{tabular}

Data kuantitatif yang telah terkumpul, dianalisis dengan deskriptif kuantitatif kemudian dikonversikan ke bentuk kualitatif. Jenis data yang dikumpulkan meliputi:

1. Data Minat belajar siswa

Variabel minat siswa terhadap pembelajaran IPA dengan pendekatan scientific dan metode inkuiri berbasis LKS diukur dengan skala Likert $1-5$ dengan jumlah pernyataan 20 butir, skor maksimum ideal 100 dan skor minimal ideal $=20$, rata-rata ideal 60 , dan standar deviasi ideal 13,33. Berdasarkan ratarata ideal dan standar deviasi ideal tersebut, skor minat siswa dapat diklasifikasikan seperti pada di bawah ini.

Tabel 2

Klasifikasi minat belajar siswa

\begin{tabular}{|c|c|c|c|}
\hline No & Kriteria & Interval & Kualifikasi \\
\hline 1 & $>(\mathrm{Mi}+1,5 \mathrm{SDi})$ & $>80$ & Sangat tinggi \\
\hline 2 & $\begin{array}{l}(\mathrm{Mi}+0,5 \mathrm{SDi}) \quad \text { s/d } \quad(\mathrm{Mi}+ \\
1,5 \mathrm{SDi})\end{array}$ & $66,67-80$ & Tinggi \\
\hline 3 & $\begin{array}{l}(\mathrm{Mi}-0,5 \mathrm{SDi}) \quad \text { s/d } \quad(\mathrm{Mi}+ \\
0,5 \mathrm{SDi})\end{array}$ & $53,34-66,67$ & Cukup tinggi \\
\hline 4 & $\begin{array}{l}(\mathrm{Mi}- \\
0,5 \mathrm{SDi})\end{array}$ & $40-53,34$ & Kurang \\
\hline 5 & $<(\mathrm{Mi}-1,5 \mathrm{SDi})$ & $<40$ & Sangat kurang \\
\hline
\end{tabular}


2. Deskripsi hasil belajar siswa

Data hasil belajar siswa meliputi:

a. Sikap ilmiah

Sikap ilmiah siswa diukur dengan skala Likert 1 - 5 dengan jumlah indikator 5, dengan skor maksimum ideal 25dan skor minimal ideal $=5$. Rata-rata ideal $=15$, dan standar deviasi ideal $=3,33$. Berdasarkan rata-rata ideal dan deviasi ideal tersebut, skor sikap ilmiah siswa dapat diklasifikasikan sebagai tertera dalam tabel 3.

b. Pengetahuan

Indikator keberhasilan untuk aspek pengetahuan adalah rata-rata hasil belajar melampaui KKM IPA kelas VIII (KKM $\geq 78)$. Ketuntasan Klasikal untuk prestasi belajar mencapai minimum $85 \%$.Berdasarkan analisis hasil ulangan siklus I diperoleh nilai rata-rata adalah 82, 14 dan ketuntasan klasikal sebesar 86\%.Pada siklus II sebesar 80, 71 dan ketuntasan klasikal sebesar 89\%.Dengan berpedoman pada indikator keberhasilan, maka rata- rata aspek pengetahuan siklus I dan siklus II melampaui KKM, untuk ketuntasan klasikal, baik siklus I dan II menunjukkan sudah tuntas.

c. Keterampilan proses IPA

Keterampilan proses siswa diukur dengan skala Likert $1-5$ dengan jumlah indikator 5, dengan skor maksimum ideal 25 , skor minimal ideal $=5$, ratarata ideal 15, dan standar deviasi ideal $=3,33$. Berdasarkan deviasi ideal tersebut, skor keterampilan proses siswa dapat diklasifikasikan sebagai tertera dalam tabel 3 berikut ini.

Tabel 3

Klasifikasi sikap ilmiah dan keterampilan proses IPA siswa

\begin{tabular}{|c|l|c|c|}
\hline No & \multicolumn{1}{|c|}{ Kriteria } & Interval & Kualifikasi \\
\hline 1 & $>(\mathrm{Mi}+1,5 \mathrm{SDi})$ & $>19.99$ & Sangat Baik \\
\hline 2 & $(\mathrm{Mi}+0,5 \mathrm{SDi}) \mathrm{s} / \mathrm{d}(\mathrm{Mi}+1,5 \mathrm{SDi})$ & $16.67-19.99$ & Baik \\
\hline 3 & $(\mathrm{Mi}-0,5 \mathrm{SDi}) \mathrm{s} / \mathrm{d}(\mathrm{Mi}+0,5 \mathrm{SDi})$ & $13.34-16.67$ & Cukup \\
\hline 4 & $(\mathrm{Mi}-1,5 \mathrm{SDi}) \mathrm{s} / \mathrm{d}(\mathrm{Mi}-0,5 \mathrm{SDi})$ & $10-13.34$ & Kurang \\
\hline 5 & $<(\mathrm{Mi}-1,5 \mathrm{SDi})$ & $<10$ & Sangat Kurang \\
\hline
\end{tabular}




\section{Deskripsi Respon siswa}

Variabel respon siswa terhadap pembelajaran IPA dengan pendekatan scientific dan metode inkuiri diukur dengan skala Likert 1-5, dengan jumlah pernyataan 15 butir, skor maksimum ideal 75 , skor minimal ideal $=15, \quad$ ratarata ideal 45, dan standar deviasi ideal 10. Berdasarkan rata-rata ideal dan standar deviasi ideal tersebut, skor respon siswa dapat diklasifikasikan sebagai tertera dalam berikut ini.

Tabel 4

Klasifikasi Respon Siswa

\begin{tabular}{|c|l|c|c|}
\hline No & \multicolumn{1}{|c|}{ Kriteria } & Interval & Kualifikasi \\
\hline 1 & $>(\mathrm{Mi}+1,5 \mathrm{SDi})$ & $>60$ & Sangat Positif \\
\hline 2 & $(\mathrm{Mi}+0,5 \mathrm{SDi}) \mathrm{s} / \mathrm{d}(\mathrm{Mi}+1,5 \mathrm{SDi})$ & $50-60$ & Positif \\
\hline 3 & $(\mathrm{Mi}-0,5 \mathrm{SDi}) \mathrm{s} / \mathrm{d}(\mathrm{Mi}+0,5 \mathrm{SDi})$ & $40-50$ & Cukup Positif \\
\hline 4 & $(\mathrm{Mi}-1,5 \mathrm{SDi}) \mathrm{s} / \mathrm{d}(\mathrm{Mi}-0,5 \mathrm{SDi})$ & $30-40$ & Kurang Positif \\
\hline 5 & $<(\mathrm{Mi}-1,5 \mathrm{SDi})$ & $<30$ & Sangat kurang Positif \\
\hline
\end{tabular}

\section{HASIL PENELITIAN DAN PEMBAHASAN}

Berdasarkan data hasil siklus I untuk rata-rata sikap sebesar 19 kategori baik, untuk ranah pengetahuan rata-rata sebesar 80,71 dengan ketuntasan $86 \%$, untuk ranah keterampilan rata-rata sebesar 18 dengan kategori baik, untuk ringkasan hasil penelitian, dapat dilihat pada tabel 5 .

Tabel 5

Ringkasan hasil penelitian

\begin{tabular}{|l|l|c|c|}
\hline \multirow{2}{*}{$\begin{array}{l}\text { Objek } \\
\text { Pengamatan }\end{array}$} & \multirow{2}{*}{ Uraian } & \multicolumn{2}{|c|}{ Hasil } \\
\cline { 3 - 4 } & & Siklus I & Siklus 2 \\
\hline Hasil belajar : & & & 20 \\
\hline \multirow{3}{*}{ a. Sikap } & Rata-rata & 19 & Baik \\
\cline { 2 - 4 } & Kategori & Baik & 82,14 \\
\hline \multirow{3}{*}{ b. Pengetahuan } & Rata-rata & 80,71 & $89 \%$ \\
\cline { 2 - 4 } & $\begin{array}{l}\text { Ketuntasan } \\
\text { Klasikal }\end{array}$ & $86 \%$ & Tuntas \\
\cline { 2 - 4 } & Keterangan & Tuntas & 19 \\
\hline c. Keterampilan & Rata-rata & 18 & Baik \\
\cline { 2 - 4 } & Kategori & Baik & \\
\hline
\end{tabular}




\begin{tabular}{|l|l|c|c|}
\hline \multirow{2}{*}{ Minat siswa } & Rata-rata & 72 & 82,45 \\
\cline { 2 - 4 } & Kategori & Tinggi & Tinggi \\
\hline \multirow{2}{*}{ Respon Siswa } & Rata-rata & \multicolumn{2}{|c|}{63,93} \\
\cline { 2 - 4 } & Kategori & \multicolumn{2}{|c|}{ Sangat Positif } \\
\hline
\end{tabular}

Mengacu data hasil penelitian pada Tabel 5 dan dengan membandingkan target atau indikator keberhasilan yang telah ditetapkan dapat dikatakan bahwa: (1) implementasi pendekatan scientific dengan metode inkuiri dalam pembelajaran IPA dapat meningkatkan minat siswa terhadap pelajaran IPA. Hal ini dapat dilihat dari skor kuesioner untuk minat siswa pada siklus I sebesar 72 dan siklus II ratarata 82,45 . Jadi mengalami peningkatan sebesar 5,7\% dengan kualifikasi tinggi, (2) implementasi pendekatan scientific dengan metode inkuiri berbantuan LKS dalam pembelajaran IPA dapat meningkatkan hasil belajar siswa. Peningkatan hasil belajar dapat dilihat dari rata-rata skor ranah sikap sebesar 19 pada siklus I, pada siklus II sebesar 20, mengalami peningkatan sebesar 5,26\%. Sedangkan hasil tes kognitif dengan rata- rata nilai siswa pada siklus I sebesar 82,14 dan siklus II sebesar 80,71.Dari data hasil rata-rata tes kognitif mengalami penurunan sebesar 1,74\%.Penurunan pencapaian nilai dapat dimaklumi karena tingkat kerumitan materi pada siklus II memang lebih rumit dibandingkan dengan materi pada siklus I. Hal ini terlihat dari analisis KKM pada dokumen II Kurikulum IPA di SMPN 1 Singaraja (Arsip MGMP IPA). Walaupun mengalami penurunan hasil, penerapan pendekatan scientific dengan metode inkuiri berbasis LKS dapat dikatakan sangat efektif dan sangat baik, hal ini dibuktikan dengan rata- rata nilai siswa baik pada siklus I dan siklus II mencapai nilai yang melampau KKM ( nilai $\mathrm{KKM} \geq 78$ ). Untuk ketuntasan belajar secara klasikal mengalami kenaikan dari siklus I ke siklus II sebesar 3,49 \% (dari 86\% menjadi 89\%), juga melampaui indikator ketuntasan klasikal yaitu 85\%. Penerapan pendekatan scientific dengan metode inkuiri dapat dikatakan efektif dan baik, Hal ini dibuktikan dengan ratarata nilai siswa baik pada siklus I dan siklus II mencapai nilai yang melampaui KKM ( nilai KKM = 78). Untuk ketuntasan belajar secara klasikal mengalami kenaikan dari siklus I ke siklus II sebesar 3,00 \% (86\% pada siklus I dan menjadi $89 \%$ pada siklus II), juga melampaui indikator ketuntasan klasikal yaitu $85 \%$. Peningkatan keterampilan proses sains siswa setelah mengikuti pelajaran IPA 
dengan metode inkuiri dapat dilihat dari adanya peningkatan rata-rata nilai siswa dari siklus I sebesar 18 dan siklus II sebesar 19. Dari siklus I ke siklus II mengalami peningkatan sebesar 5,26\%. (3) Respon siswa terhadap pendekatan scientific dengan metode inkuiri dapat dikatakan sejalan dengan keinginan siswa, hal ini dapat dilihat dari rata rata skor siswa sebesar 63,93, tergolong kategori sangat positif.

Dari catatan peneliti dan observer didapatkan data tentang permasalahanpermasalahan yang dihadapi saat pembelajaran berlangsung dan solusi pemecahannya:

Pada siklus I ditemukan lima siswa yang tidak mampu menyelesaikan tugas tepat pada waktunya (berkaitan dengan sikap desiplin), untuk siklus II ada satu siswa. Pada kategori sikap keaktifan siswa, beberapa siswa pada siklus satu, tampak kurang aktif dalam pembelajaran.Solusi dari permasalahan di atas yaitu dengan cara masing-masing siswa harus mengumpulkan tugas hasil diskusinya dan dipahami agar mampu dipresentasikan di depan kelas. Selain itu siswa juga menyiapkan pertanyaan untuk materi yang kurang dipahami. Hasil penelitian siklus I dideskripsikan sebagai berikut. Dari beberapa indikator pencapaian kompetensi dasar tentang menjelaskan struktur dan fungsi sistem eksresi pada manusia dan penerapannya dalam menjaga kesehatan diri.ditemukan beberapa anak mengalami kesulitan. Indikator-indikator dan jumlah anak yang mengalami kesulitan pencapaiannya,antara lain: (1) menjelaskan hubungan struktur dan fungsi pada organ ginjal. Ada tiga siswa menyatakan belum memahami. (2) Menjelaskan hubungan struktur dan fungsi pada organ kulit. Ada tiga siswa menyatakan belum memahami. (3) Mengidentifikasi kelainan dan penyakit yang terjadi pada sistem ekskresi. Ada dua siswa menyatakan belum memahami.

Hasil penelitian siklus II dideskripsikan sebagai berikut. Indikatorindikator dan jumlah anak yang mengalami kesulitan pencapaiannya, antara lain: (1) Mendeskripsikan hubungan antara periode, frekuensi, cepat rambat gelombang, dan panjang gelombang. Ada lima anak menyatakanbelum memahami. (2) Mengidentifikasi gejala resonansi dalam kehidupan seharihari.Ada empat anak menyatakan belum memahami. (3) Mendeskripsikan sistem 
sonar serta pemanfaatan sistem sonar dalam teknologi. Ada satu anak menyatakan belum memahami. Solusi pemecahan masalah dalam kesulitan pencapaian indikator pada ranah pengetahuan yaitu mengadakan pengulangan materi (review materi) saat refleksi pembelajaran.

Kesulitan pencapaian kompetensi pada ranah keterampilan dideskripsikan sebagai berikut. Pada siklus I yaitu Ada beberapa orang siswa tampak masih kebingungan saat melakukan percobaan dan saat menganalisis data dari hasil percobaan mereka. Dari hasil refleksi pada siklus I, sehingga pada siklus II dilakukan perbaikan berupa penekanan-penekanan mengenai langkah-langkah keterampilan proses sains yang harus dilakukan siswa dan diberikan lebih banyak pertanyaan yang sifatnya membimbing dan menuntun dalam percobaan.

Setelah dilakukan perbaikan-perbaikan dalam pembelajaran, tampak siswa aktif melakukan kegiatan belajar sesuai dengan tahapan-tahapan keterampilan proses sains yang ada pada LKS, kegiatan melaksanakan investigasi melalui percobaan, membuat analisis tentang hasil percobaan, membahas data/informasi yang diperoleh, mengajukan solusi-solusi terhadap masalah-masalah yang dihadapi, membuat kesimpulan tentang hasil percobaaannya, menyusun laporan, dan mempresentasikan laporannya di depan kelas. Semua kegiatan belajar ini dilaksanakan dalam kelompok.

Terkait dengan minat siswa berdasarkan hasil pengamatan peneliti, sebagian anak mengalami masalah dalam pembelajaran pada siklus I antara lain; kurang konsentrasi, enggan bertanya, ada dua siswa menyatakan sulit mengerti dengan penyajian dari guru, dan tiga siswa menyatakan masih kurang contohcontoh yang diberikan oleh guru. Solusi berkaitan dengan minat siswa meliputi: (1) Memberikan motivasi berupa pendekatan secara perorangan (guru duduk di samping siswa yang mengalami kesulitan dalam pembelajaran, menanyakan halhal yang tidak dimengerti siswa, dan memberikan bimbingan agar siswa dapat mengerti materi yang disajikan tersebut. (2) Memberikan perhatian-perhatian dengan memberi pertanyaan-pertanyaan pada siswa, memberi pujian pada siswa yang mampu menjawab secara benar, menuntun siswa yang kurang mampu dalam pelajaran. (3) Lebih banyak menekankan pada contoh-contoh agar siswa mudah 
mengerti materi pelajaran tersebut. (4) Memformulasikan pertanyaan-pertanyaan yang mudah dimengerti siswa.

Secara umum, peranan guru dalam pembelajaran ini adalah membimbing siswa dalam mengerjakan LKS, membimbing siswa dalam melaksanakan investigasi, membimbing siswa dalam menyusun laporan, membimbing siswa dalam menyajikan laporan atau presentasi kelas. Di samping itu, pada saat diskusi kelas, guru memperbaiki kesalahan-kesalahan konsep siswa.Satu hal yang juga dilakukan guru dalam pembelajaran ini adalah guru menyajikan konsep-konsep IPA dengan memberikan pertanyaan- pertanyaan dalam kegiatan belajar siswa. Penggunaan pertanyaan merupakan suatu hal yang esensial sebagai panduan dalam penemuan, dan dapat memfasilitasi siswa belajar lebih baik (Carin \& Sund, 1985).Gulo (2002) dan Trowbridge \& Bybee (1990) menguraikan bahwa bertanya memiliki peran untuk meningkatkan sikap inkuiri serta dapat membantu siswa berpikir kritis.

Berdasarkan hasil tersebut, dapat dikatakan bahwa penerapan pendekatan scientific dengan metode inkuiri dalam pembelajaran IPA dapat meningkatkan minat dan hasil belajar siswa. Pendekatan scientific dengan metode inkuiri dan lebih menekankan pada aktivitas siswa. Siswa selalu bekerja sama dalam menemukan konsep yang dibaca dari buku, melakukan penyelidikan, mengomunikasikan gagasan-gagasannya sehingga dapat membangun konsepkonsep dengan mengaitkan pengalaman yang di dapat pada saat melakukan eksperimen dengan pengetahuan teori yang dimiliki (dari hasil membaca buku), tanpa terlepas dari peran guru sebagai motivator dan fasilitator.

Pemilihan pendekatan scientific dengan metode inkuiri dalam pembelajaran IPA dilandasi pemikiran bahwa keberhasilan pembelajaran terletak pada beberapa faktor yaitu siswa, guru, lingkungan, fasilitas dan pendukung yang lain. Oleh karena itu, siswa, guru dan fasilitas pendukung perlu diberdayakan melalui poses pelaksanaan pembelajaran menggunakan pendekatan scientific dengan metode inkuiri.

Melalui Pendekatan scientific siswa diberi kesempatan untuk beraktivitas seperti ilmuwan, salah satu cara untuk mengembangkan sikap ilmiah adalah 
dengan memperlakukan anak seperti ilmuwan muda sewaktu anak mengikuti kegiatan pembelajaran sains. Mereka terbiasa mengamati, mengaplikasikan pengetahuan, berhipotesa, merencanakan penelitian, mengomunikasikan temuan. Ilmuwan juga memiliki sikap ilmiah seperti jujur dalam merekam data faktual, tekun dalam menyelesaikan tugas, terbuka pada kebenaran ilmiah dan selalu mendahulukan kebenaran yang diperoleh dengan cara dan metode ilmiah, kritis dalam menanggapi setiap preposisi/pernyataan/pendapat, kreatif sewaktu melakukan percobaan/penelitian. Pendekatan scientific dilakukan untuk melatih sikap, pengetahuan dan keterampilan ilmiah pada siswa. Untuk maksud ini siswa memerlukan lebih banyak doing science dari pada listening to scientific knowledge. Dalam kegiatan pembelajaran berbantuan LKS mewajibkan siswa membaca buku untuk menumbuhkan kebiasaan positif siswa dan menumbuhkan minat siswa untuk belajar, dan pemberian LKS dapat mendorong siswa bekerja secara kolaboratif dan membantu siswa mendapatkan pengetahuan, keterampilan dan sikap secara aktif. Penggunaan LKS juga sangat cocok untuk pembelajaran dengan metode inkuiri. Hal ini sesui dengan pendapat Darmodjo \& Kaligis (1992), bahwa penggunaan LKS dalam pembelajaran dapat membantu guru mengarahkan siswanya untuk menemukan konsep-konsep melalui aktivitas individual atau kelompok, dapat pula digunakan mengembangkan keterampilan proses sains, sikap ilmiah dan membangkitkan minat siswa terhadap alam sekitar. Hal ini dapat dilihat dari penelitian ini, siswa sangat antusias dalam belajar. Tampak dari kegiatan ilmiah yang dilakukan dengan dukungan data atau informasi yang sangat lengkap. Aktivitas diskusi baik dalam kelompok maupun diskusi kelas sangat baik, yang dapat dilihat dari hampir semua siswa ingin menyampaikan pendapat dalam kegiatan diskusi. Tanggapan terhadap masalah yang diajukan dalam diskusi kelas tidak hanya diberikan oleh kelompok yang melakukan tugas presentasi. Tanggapan juga diberikan oleh kelompok lain membantu kelompok yang sedang presentasi. 


\section{PENUTUP}

Berdasarkan hasil penelitian dan pembahasan dapat disimpulkan sebagai berikut: (1). Implementasi pendekatan scientific dengan metode inkuiri dalam pembelajaran IPA dapat meningkatkan minat siswa terhadap pelajaran IPA. Hal ini dapat dilihat dari hasil kuesioner untuk minat siswa kualifikasi tinggi. (2). Implementasi pendekatan scientific dengan metode inkuiri dalam pembelajaran IPA dapat meningkatkan hasil belajar siswa. (3). Respon siswa terhadap pendekatan scientific dengan metode inkuirisangat sangat positif.

Mengacu pada hasil penelitian tersebut dapat diajukan saran-saran, yaitu ; (1) Penerapan pendekatan scientific dengan metode inkuiri dapat digunakan sebagai salah satu alternatif dalam upaya meningkatkan hasil belajar IPA. (2) Penerapan pendekatan scientific dengan metode inkuiri memerlukan adanya arahan dari guru secara maksimal karena siswa masih pada taraf pra operasi formal.

\section{DAFTAR PUSTAKA}

Anggareni, N. W., Ristiati, N. P. dan Widiyanti, N. L. P. M. 2013. Implementasi Strategi Pembelajaran Inkuiri Terhadap Kemampuan Berpikir Kritis dan Pemahaman Konsep IPA. e-Journal Program Pascasarjana Universitas Pendidikan Ganesha Program Studi IPA, Volume 3 Tahun 2013.

Depdiknas. 2013. Kurikulum SMP mata pelajaran IPA kelasVIII. Jakarta: Depdiknas.

Gulo, W. 2002.Strategi Belajar Mengajar. Jakarta: Grasindo.

Kariasa, I.N., dan I Wayan Suastra. 2005. Mengembangkan Inkuiri Terbimbing (Guided Inqury) dalam Pembelajaran Sains di Sekolah Dasar. Laporan Penelitian. Undiksha Singaraja./t,p/

Negoro, ST. \& Harahap, B.,1984. Ensiklopedia Matematika .Bandung: Ghalia Indonesia

National Research Council. 2000. Inquiry and the National Science Education Standards: A Guide for Teaching and Learning. Washington: National Academy Press. 
Sabahiyah., Marhaeni, A. A. I. N. dan Suastra, IW. 2013. Pengaruh Model Pembelajaran Inkuiri Terbimbing Terhadap Keterampilan Proses Sains dan Penguasaan Konsep IPA Siswa Kelas V Gugus 03 Wanasaba Lombok Timur. e-Journal Program Pascasarjana Universitas Pendidikan Ganesha Program Studi Pendidikan Dasar. Volume 3 Tahun 2013.

Santyasa, IW., Warphala, IW. S. dan Tegeh, IM. 2014. Analisis Kebutuhan Pengembangan Model-Model Student-Centered Learning Untuk Meningkatkan Penalaran dan Karakter Siswa SMA. Jurnal Pendidikan Indonesia, Vol. 3, No. 1, April 2014.

Sugiyanto. 2000. Model-Model Pembelajaran Inovatif. Surakarta : Yama Pustaka.

Tileston,D.W. 2007 Teaching Strategis for Active Learning. Essentials for Your Teaching Plan. USA: Corwin Press.

Trianto.2015. Menedesain Model Pembelajaran Inovatif-Progresif.Jakarta : Kencana Prenada Media Group.

Trowbridge, L. W. and Bybee, R. W. 1990.Becoming a Secondary School Science Teacher. Colombus: Merrill.

Warta, Nyoman. 2011. Penerapan Model Guided Inquiry Melalui Setting Pembelajaran Kooperatif Tipe STAD dalam Pembelajaran Kabupaten Buleleng Volume 1 Nomor 3, Oktober 2011. 